\title{
Should we treat minimal breast cancer lesions?
}

\author{
Yoshinori Ito
}

Published online: 28 December 2011

(C) The Japanese Breast Cancer Society 2011

To date, the multiple weapons of systemic treatments with chemotherapy, endocrine- or molecular-target agents, combined with local surgery or radiation, have improved survival in patients with breast cancer [1, 2]. However, for each individual patient, it is not yet clear how to choose the best path to achieve a cure [3]. Breast cancer consists of heterogeneous diseases with different phenotypes. DNA microarray has provided intrinsic subtypes of breast cancer, e.g., luminal A, luminal B, human epidermal growth factor receptor type 2 (HER2)-enriched, basal-like, or claudinlow, normal breast-like subtype [4-7]. Anti-HER2 agents have dramatically improved the prognosis of patients with HER2-enriched breast cancer [8, 9]. However, a minimally invasive ductal carcinoma, even HER2-enriched, can be cured by local treatment alone. When do we need systemic therapeutic agents? Araki et al. reported that HER2 overexpression is a risk factor for recurrence of breast cancer with tumors smaller than $1.0 \mathrm{~cm}$ (T1a-b N0M0). AntiHER2 systemic treatment may provide a clinical benefit for HER2-overexpressed T1a-b breast cancer. In contrast, the natural prognosis of luminal A and B subtypes, which comprise the majority of breast cancers, differs distinctly. Low proliferative luminal A demonstrates better prognosis than luminal B, with 80 versus 50\% 10-year relapse-free survival [10]. The highly proliferative luminal B type requires systemic cytotoxic chemotherapy. The guidelines of the National Comprehensive Cancer Network recommend administering adjuvant chemotherapy for $0.5-1.0 \mathrm{~cm}$-sized luminal (estrogen receptor positive/

\section{Y. Ito $(\square)$}

Department of Medical Oncology, Breast Oncology Center, Cancer Institute Hospital, Japanese Foundation for Cancer Research, 3-8-31 Ariake, Koto-ku, Tokyo 135-8550, Japan e-mail: yito@jfcr.or.jp
HER2 negative) breast cancer without axillary lymph node metastasis with a high recurrence score of Oncotype DX ${ }^{\circledR}$, with additional chemotherapy for tumors of any size with axillary lymph node involvement (http://www.ncen.org/ professionals/physician_gls/pdf/breast.pdf). The optimal range for surgical resection of axillary lymph nodes has been discussed by Imoto et al. Isolated tumor cells and micrometastases in sentinel lymph nodes were associated with worse survival in patients treated with sentinel node biopsy (SNB) alone or SNB followed by axillary lymph node dissection. Imoto et al. proposed that in patients with $\mathrm{T} 1(<2 \mathrm{~cm})$ and one positive sentinel lymph node who are treated with whole-breast irradiation and adjuvant therapy, additional axillary lymph node dissection may not be necessary. It is reasonable that adjuvant systemic therapy and radiation could influence the optimal range of surgical resection. Luminal A type appears to be safe at a relatively larger size, unless involving metastasis of the axillary lymph nodes. Cancer cells may exist in axillary nodes as solitary cells or micro- or overt macro-metastasis. A small amount of cancer cells in axillary nodes can be ignored for local treatment. The thresholds of recurrence would differ in the primary site or axillary node, or in each subtype.

Recent biological analysis has demonstrated the complexity of surviving breast cancer cells. Cancer stem cell theory reveals a diversity or heterogeneity of cancer cells $[11,12]$. It is difficult to abolish the true target cells that evoke a recurrence. Cancer cells are able to escape into dormant G0 status, convert to epithelial-mesenchymal transition (EMT) [13], enter the bloodstream as circulating tumor cells (CTC) [14, 15], or hide as disseminated tumor cells (DTC) [16] in sanctuary niches of bone marrow [17]. Each subtype may or may not harbor stem cells or progenitor cells. Hayashi et al. have reviewed the current knowledge on CTC and DTC. Imamura et al. have focused 
on the transforming growth factor- $\beta$ signaling that is a potent regulator of EMT and cell stemness, suggesting possible targets to control minimal breast cancers in the microenvironment.

In the children's book series "Where's Waldo?", Waldo wears a red-and-white striped shirt, bobble hat, and round black glasses. However, numerous similar red-and-white striped objects surround him. What color does the true target of cancer cells wear? $\mathrm{CD} 44^{+} / \mathrm{CD} 24^{\text {low }} /$ aldehyde dehydrogenase-positive cell-surface markers? How can we pick them out? Which cancer cells can we ignore? Further investigations are required to answer these questions. The four review articles provide us with updated information and hint at developing the optimal treatment for minimal breast cancer lesions. A breadth of scientific knowledge and elegant multiple weapons are mandatory to establish the optimal treatment for eradicating cancer cells.

\section{References}

1. Jemal A, Ward E, Thun M. Declining death rates reflect progress against cancer. PLoS One. 2010;5:e9584.

2. Bosetti C, Bertuccio P, Levi F, Chatenoud L, Negri E, La Vecchia C. The decline in breast cancer mortality in Europe: an update (to 2009). Breast. 2011 (Epub ahead of print).

3. Ito Y, Iwase T, Hatake K. Eradication of breast cancer cells in patients with distant metastasis: the finishing touches? Breast Cancer. 2011. (Epub ahead of print).

4. Perou CM, Sørlie T, Eisen MB, van de Rijn M, Jeffrey SS, Rees CA, et al. Molecular portraits of human breast tumours. Nature. 2000;406:747-52.

5. Sørlie T, Perou CM, Tibshirani R, Aas T, Geisler S, Johnsen H, et al. Gene expression patterns of breast carcinomas distinguish tumor subclasses with clinical implications. Proc NatlAcad Sci USA. 2001;98:10869-74.
6. Sørlie T, Tibshirani R, Parker J, Hastie T, Marron JS, Nobel A, et al. Repeated observation of breast tumor subtypes in independent gene expression data sets. Proc Natl Acad Sci USA. 2003;100:8418-23.

7. Prat A, Parker JS, Karginova O, Fan C, Livasy C, Herschkowitz JI, et al. Phenotypic and molecular characterization of the claudin-low intrinsic subtype of breast cancer. Breast Cancer Res. 2010;12:R68.

8. Slamon DJ, Leyland-Jones B, Shak S, Fuchs H, Paton V, Bajamonde A, et al. Use of chemotherapy plus a monoclonal antibody against HER2 for metastatic breast cancer that overexpresses HER2. N Engl J Med. 2001;344:783-92.

9. Dahabreh IJ, Linardou H, Siannis F, Fountzilas G, Murray S. Trastuzumab in the adjuvant treatment of early-stage breast cancer: a systematic review and meta-analysis of randomized controlled trials. Oncologist. 2008;13:620-30.

10. Parker JS, Mullins M, Cheang MC, Leung S, Voduc D, Vickery $\mathrm{T}$, et al. Supervised risk predictor of breast cancer based on intrinsic subtypes. J Clin Oncol. 2009;27:1160-7.

11. O'Brien CA, Kreso A, Jamieson CH. Cancer stem cells and selfrenewal. Clin Cancer Res. 2010;16:3113-20.

12. Kai K, Arima Y, Kamiya T, Saya H. Breast cancer stem cells. Breast Cancer. 2010;17:80-5.

13. Iwatsuki M, Mimori K, Yokobori T, Ishi H, Beppu T, Nakamori $\mathrm{S}$, et al. Epithelial-mesenchymal transition in cancer development and its clinical significance. Cancer Sci. 2010;101:293-9.

14. Mostert B, Sleijfer S, Foekens JA, Gratama JW. Circulating tumor cells (CTCs): detection methods and their clinical relevance in breast cancer. Cancer Treat Rev. 2009;35:463-74.

15. Sun YF, Yang XR, Zhou J, Qiu SJ, Fan J, Xu Y. Circulating tumor cells: advances in detection methods, biological issues, and clinical relevance. J Cancer Res Clin Oncol. 2011;137: 1151-73.

16. Vincent-Salomon A, Bidard FC, Pierga JY. Bone marrow micrometastasis in breast cancer: review of detection methods, prognostic impact and biological issues. J Clin Pathol. 2008;61: $570-6$.

17. Kaplan RN, Riba RD, Zacharoulis S, Bramley AH, Vincent L, Costa C, et al. VEGFR1-positive haematopoietic bone marrow progenitors initiate the pre-metastatic niche. Nature. 2005;438: $820-7$. 